\title{
South Africa takes steps to tackle HIV
}

\section{CAPE TOWN}

At last, the South African government seems to have agreed to tackle the AIDS pandemic in a whole-hearted manner. Admitting that "we all know that HIV and AIDS are among us", deputy President Phumzile Mlambo-Ngcuka appealed to South Africans on 1 December, World AIDS Day, to "join hands to save our people, in the same way that we joined hands to fight and defeat apartheid".

At a rally in Nelspruit, the capital of South Africa's Mpumalanga province, MlamboNgcuka released a draft of the government's plan. The document contains only two targets: to halve the rate of infection, and to make antiretroviral treatment available to $80 \%$ of those who require it, both by the end of 2011 .

Mlambo-Ngcuka also declared her intention to restructure the South African National AIDS Council to include representatives from the private sector, trade unions and non-governmental organizations. No information is available on how the targets will be met - the government plans to finalize the details by March. But the developments have been greeted with cautious optimism by AIDS activists and practitioners.

"If enough funds are provided, and ifhuman resources problems - particularly relating to nurses - can be resolved, treatment targets are achievable," says economist Nicoli Nattrass, director of the AIDS and Society research unit at the University of Cape Town.

South Africa has previously taken an ambivalent approach to HIV. President Thabo Mbeki

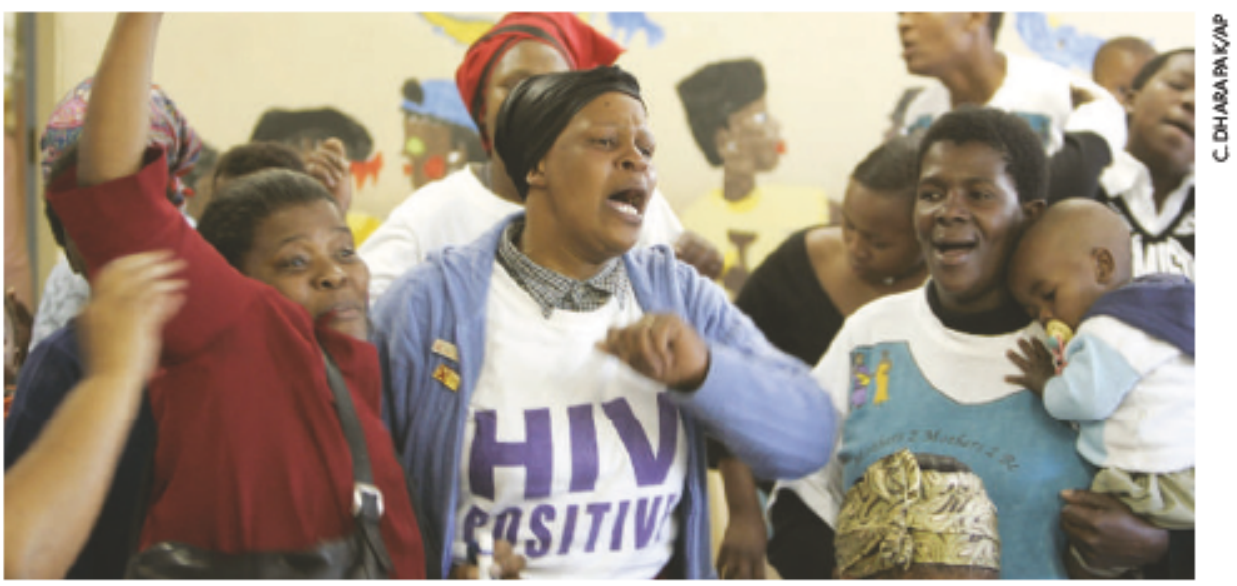

South Africans face a brighter future now their government is set for serious action on HIV.

has maintained a stony silence on the issue, and with no coordinated national strategy to provide antiretroviral drugs to patients, access to treatment has been patchy at best.

Many see the Worlds AIDSCongress, held in Toronto, Canada, in August, as a turning point. The government was embarrassed by health minister Manto Tshabalala-Msimang, who used it to extol the virtues of garlic, lemon and beetroot in the fight against AIDS. MlamboNgcuka, who many see as a possible successor to Mbeki, quickly assumed responsibility for government policy on the issue.

She faces a tough task. A report released last week by the Actuarial Society of South Africa (ASSA) stated that 1.8 million people have died of AIDS in South Africa since the early 1990s. Between 800,000 and 1 million people need antiretroviral treatment but only a third of them - and a tenth of children - are getting it.

Slowing down rates of infection might be even more difficult. The ASSA estimates that half a million people became infected this year, down from 650,000 in 1998.

But the signs are promising. In 2005, $1.7 \mathrm{mil}$ lion people used government counselling and testing services, and this year the number of people treated for HIV nearly doubled. Last week the deputy health minister, Nozizwe MadlalaRoutledge, became the first government minister to publicly undergo an AIDS test. Michael Cherry

\section{Oil firms back AIDS project in the Niger delta}

BONNY ISLAND, NIGERIA

Oiland gascompanies have set up a three-year project to tackle the rapid s pread of AIDS around one of the largest facilities in the Niger delta.

King EdwardXI of Bonny Island announced the partnershipon 1 December, World AIDS Day, saying he hoped it would "rouse the community into action" and lead to free treatment for people living with HIV/AIDS. The island, with a population of about 150,000 , houses a vast US\$15-billion liquefied natural-gas plant.

The Bonny Island initiative, named lbani-se, is initially being supported by Niger ia Liquified Natural Gas, Shell and Exxon-Mobil to address the welfare of the local community. The companies spent $\$ 600,000$ to startit this year and are expected to put in another $\$ 1.4$ million in 2007.

The initiative is led by Donald de Korte, a physician and consultant to drug company Merck, who used to run the African Comprehensive HIV/ AIDS Partnerships in Botswana. The planis to consult local people and establish lbani-se as a communitybased project funded not just by oil and gas companies but by sources such as the Global Fund to Fight AIDS, Tuberculosis and Malaria.
The challenges of operating in the lawless and volatile delta mean little has beendone so far to confront the menace of AIDS. High infection rates are fuelled, researchers suspect, by rampant sexual interaction between oil workers, other migrant labour and the many sex workers who surround the oil and gas facilities. Project officials chose Bonny Island because it provides a distinct entity for monitoring and treatment, and is stably governed by the king. It is one of the few places in the delta secure enough for such an initiative to work.

A survey of 800 households suggests that the AIDS prevalence on the island is around $8 \%$, almost twice the national average. The project plans to counsel and test 30,000 people for HIV over three years, and offer antiretroviral treatment at Bonny General Hospital, the island's dilapidated medical facility. "The first priority is to equip ands staff the hospital properly," says Douglas Pepple, its senior physician.

The project's organizers hope to have 50 patients on antiretroviral drugs by the end of 2007 , and 800 (a quarter of those estimated to need them) by the end of 2009. Colin Macilwain 